\title{
Do Google Trends and Shariah Compliant Stocks Co-Integrated? An Evidence from India
}

\author{
Mohammad Irfan \\ School of Business, Auro University, Surat, Gujarat, India.
} Corresponding email: Mohammad.irfan@aurouniversity.edu.in

\begin{abstract}
The objective of the study is to understand the dynamic relationship between Shariah-compliant stocks and the Google search value index (GSVI). The search strength is identified by the search volume of Shariah-compliant stocks on Google. The sample for the study consists of Shariah-compliant stocks commonly available in all the three Shariah indices in India, sample stock data has been extracted on a weekly basis from Sept 2014 to Sept 2019. The results of the study are based on the diagnostic analysis suggests that there is no serial correlation as demonstrated by LM residual test, CUSUM test shows stability in data, coefficient Wald test is showing there is no short-run causality running between selected Shariah-compliant stocks and GSVI. The outcome suggests that there is a long-run equilibrium relationship existing between Shariah-compliant stocks and the Google search value index. Trace statistics has five co-integration equations and Max-Eigen statistics has one cointegration. The vector error correction model (VECM) suggests the acceptability of the model. There are many potential investment opportunities for investors in the Islamic stock market of India. The motive of Shariah is to provide an avenue for ethical and viable investment to the investors. This study will not only be advantageous for the Muslim investors but also the other investors, industrialist, Shariah-compliant advisor as well.
\end{abstract}

Keywords: Nifty Shariah Indices, google trends, co-integration, granger causality. JEL Classification: G10, G17.

@ IJIEF 2020 published by Universitas Muhammadiyah Yogyakarta, Indonesia

DOI:

https://doi.org/10.18196/ijief.3228
Web:

https://journal.umy.ac.id/index.php/ijief/article/view/8958

Citation:

Irfan, M. (2020). Do Google Trends and Shariah Compliant Stocks Co-Integrated? An Evidence from India. International Journal of Islamic Economics and Finance (IJIEF), 3(2), 227-250. DOI: https://doi.org/10.18196/ijief.3228 


\section{Introduction}

\subsection{Background}

Google trends is tool which is provided by Google, represents in graphs and numbers on the behalf of the popularity of special search on google. Psychology of people now changed before buying and investing they will google things knows that fact about the thing. This google trends help them to identify the frequency of the item, the range of frequency in between 1100 , higher the frequency higher will be the demand of product \& services, industry, company, item, etc.

Nowadays, with the help of advancement in technology like the internet, the use of Google search has increased. Internet has become the core source of information for people across the world. Google trends collects the data of the user's behavior, most recent search terms, etc. In the search items some of the data are publicly available on Google trends. In terms of global scale this data tells very important aspects about human information gathering activities. Its open new opportunities to identify collective decision making (Curme, Stanley, Moat, \& Preis, 2014). In the past, it was very difficult to predict stock market trends. The stock market is definitely affected by the macro-micro condition of the countries and for this historical data was used in forecasting stock market movements. In the present context, Google search value index (GSVI) becomes more popular term, people are tend to seek data or information from the Internet and express opinions on social networks (The Invest, 28). Google trends permit researchers to analyze terms which are frequently searched. It helps in explaining search volume terms like bullish and bearish. It helps in drawing the sentiment index of the investors. In investment research Google trends data are play an important role and open exciting frontiers of the research in the stock market return. It are starts with a Google search which stock gives highest return or stable. Google trends also explore the how many new investors enter into the market in most recent years (Seeking Alpha, 2018). Google is not limited to the search engine. Many of researchers have proved that, it is like a barometer of public opinion and the voice of the world at any given point of time. Google trends track the frequency of search terms entered in Google. Analytics revealed that Google trends track the seasonal pattern, it also helps in the making strategy for investing in the stock market (Stromberg, 2013). Google is the well-known search engine all over the world. It maintains records of search statistic for items or terms and reflects them in Google trends. In previous years Google searches have been used as a proxy for investor attention and also used to measure the sentiment of the investors and customer attention (Laurens, Glenn, \& Eirik, 2015). The sentiment of the 
Irfan | Do Google Trends and Shariah Compliant Stocks Co-Integrated? An Evidence from India

investors is the good sign for other investors for trading in the stock market. With the invention of internet technology, it becomes easy to find availability of information also the recently observed sentiment of the market, all this information people can get easily with the help of online search invention. Investor sentiments are studied based on the search keywords about companies (Dimpfl \& Kleiman, 2017). The term Buy, most of them used with respective company name, when people search for this type of data it indicates the investor interest in that particular company. Google trends are such an amazing tool for gathering vast data. Most of the decisions of the investors are also made up by this type of search (Krishnan, V, \& Sureshkumar, 2018).

Google search value index (GSVI) is the combination of the actual search and average search over the period of time.

$$
\text { GSVI = Actual Number of Search /Average Number of Search }
$$

To control overall increased in the number of internet search over period of time (Latoeiro, Ramos, \& Veiga, 2013).

The current study focuses upon examining the relationship between the google search queries of the Sariah compliant stocks and their volatility by investigating the causality and the extent of responsiveness of Islamic stocks and GSVI. This relationship is important for two reasons viz, for investors to know the impact of google trends on the Islamic stock market in India and for governments to take precautionary action to avoid the possible financial downturn in their respective countries due to investor perception based on google trends.

\section{Shariah Compliant Indices in India}

Shariah Indices consist of socially responsible investment (SRI) products in India. The SRI offer the product to those who wants to invest in Shariah compliant stocks. Shariah compliant stocks are not only attractive to Muslim investors but also Non-Muslim investors, these instruments are based on the Islamic faith to invest without violating their religious principles of the Islam (NSE Indices, 2018). 


\section{Nifty500 Shariah Index}

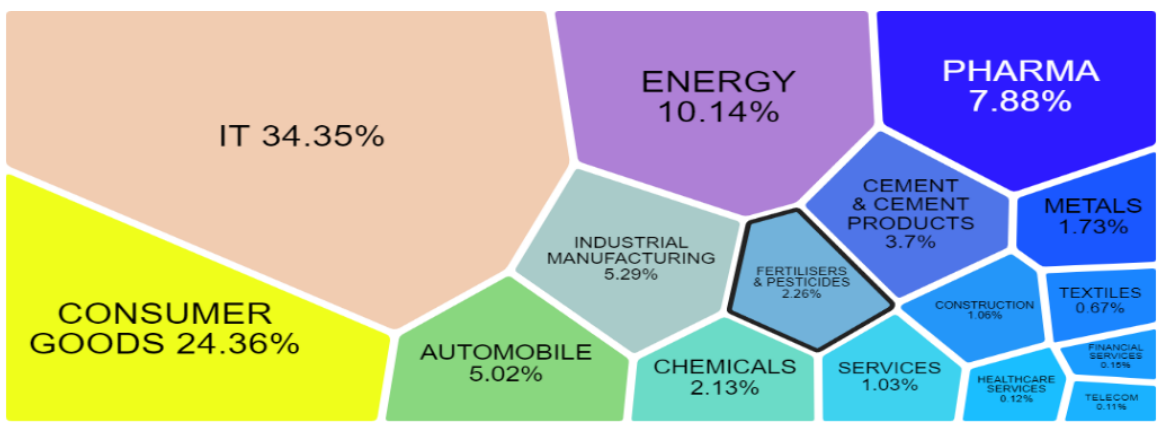

Sources: (NIFTY500 Shariah index, 2019)

The NIFTY500 Shariah index covers more than $90 \%$ of the total market capitalization and $80 \%$ of total traded volume on the NSEs. Shariah Indices are screened by Shariah principles (NSE Indices, 2018).

\section{Nifty50 Shariah Index}

This index is based on the principle of Shariah compliant and also screened by Shariah compliance. Nifty50 Shariah track the performance of parent index (NSE Indices, 2018).

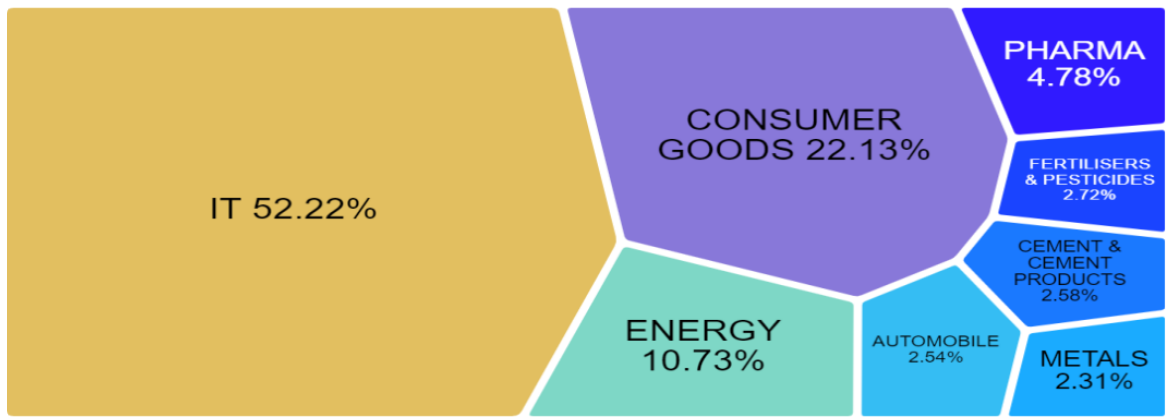

Sources: (NIFTY50 Shariah index, 2019)

\section{Nify25 Shariah Index}

Nifty25 Shariah index is independent and have fixed number of scripts in it. This index is different from the Nifty 500 Shariah and Nifty50 Shariah Index. It does not give the open platforms to the all constituents (NSE Indices, 2018).

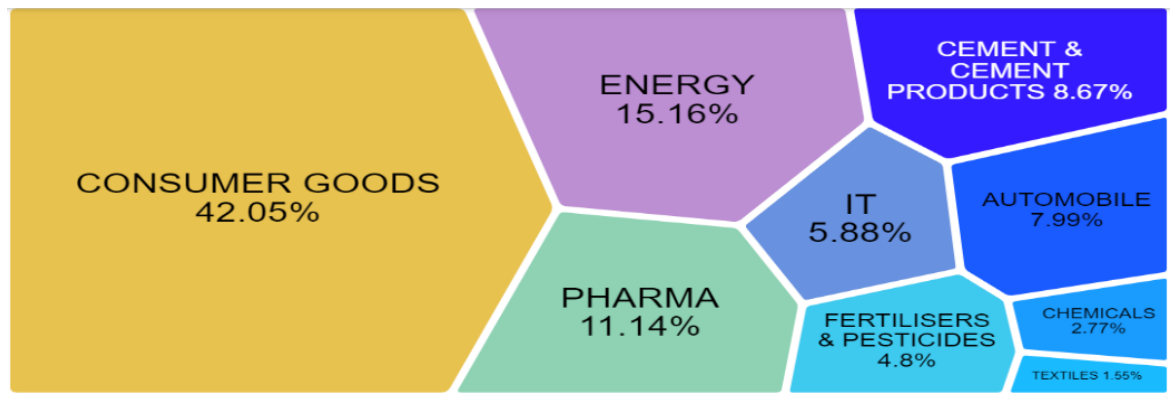

Sources: (NIFTY Shariah 25, 2019) 


\subsection{Objectives of the Research}

Basically, this paper focused inter-linkage between on the google trends (keywords of web search) and the company trends line. Whether, these are correlated or not, study also know about the short term and long-term relation association between Google trends and Shariah complaint stocks. To check the robustness of the data in term of efficiency and stability. The objective of study is to understand the dynamic relationship between Shariah compliant stocks and google trend (GSVI).

This paper have selected Shariah complaints which were continuously working in the Shariah index series of India from sept 2014 to sept 2019 namely viz, Infosys Ltd., Tata Consultancy Services Ltd., Hindustan Unilever Ltd., Asian Paints Ltd., HCL Technologies Ltd., Titan Company Ltd., Tech Mahindra Ltd., Oil \& Natural Gas Corporation Ltd., Hero Motor Corporations Ltd., Britannia Industries Ltd.

\section{Literature Review}

\subsection{Background Theory}

There are a number of studies discussed about the Google search queries (GSVI). The objective of the study is to examine the relationship between Shariah compliant stocks and Google search index value (GSVI). In the past, it works as assets pricing model on the basis of efficient market hypothesis. Efficient market covers the market price which reflects all the available information (Fama 1976). In the real-world investors do not have the access of all the information, but now-a-days, anyhow they have collected the week information, semi-strong information and strong information. But important thing is, which information is directly associated with your problem and solution, as this intention is called cognitive activity (Kahneman 1973). This reality may determine the efficient market hypothesis, and then invite the question to the investors, and what extent market prices are reflects according to the interest of the investors. According to Merton (1987), investors intention is directly associated with the stock prices and its liquidity. It is really difficult to measure the degree of investor's intention. Here, Google trends provide the online services to measure the investor's intention.

Takeda and Wakao (2014), analyzes the relationship between intensity of online search and behavior of stock-trading. Data were gathered from 189 Japanese stocks, period ranging from 2008 to 2011. The result of the study revealed that there is strongly positive correlation between weakly positive 
stock returns and trading volume. It also suggested that increases of trading activity associated with the increase of search actively. This study also stated that online search intensity and stock trading behavior have positively strong correlation, and trading volume and weekly returns have positive correction. Bijl, Kringhaug, Molnár, and Sandvik (2016) This study explored the search index value and stock returns have high co-relation. In the year range 200813 found the google search value has negative impact on the stock returns.

Dimpfl and Kleiman, (2017) Study focused on the co-moment stock market and internet search. This study found the strong co-moment in between realized volatility of market index and search value index. Granger test identified the bi-directional relationship in between the indices.

\subsection{Previous Studies}

Aouadi, Arouri, \& Teulon (2013) Found that the influence of investor attention to stock market volatility. The French stock market data were used for the study. On the basis of investors' online search behavior, researcher constructs a non-standard proxy of investor attention. Result of the study shows that there is strong correlation between trading volume and investor attention.

Smet (2015) identified profitable trading strategy using internet search engine data. Author also tried to construct a profitable trading model by using search volume data. The study found that there is correlation between market index returns and search volumes changes. It is also revealed that degree of financial relevance and performance of a word is positively correlated with each other.

Tower (2015) predict stock movements within the tech sector using Google search volume Index. The study used weekly data from April 2004 to March 2015. Within this, three different time periods correlations were established. Result of the study shows that there is strong positive correlation between weekly trading volume and Google SVI.

Laurens, Glenn, and Eirik (2015) forecast stock returns of different time period by using google search statistic and also identify trading strategies by using their models. They used Google search data of daily, weekly and quarterly. The data were collected from the period ranging from 2010 to 2014. The result of the study found that there is short-term positive relationship between daily searches and excess stock returns.

International Journal of Islamic Economics and Finance (IJIEF), 3(2), 227-250| 232 
Irfan | Do Google Trends and Shariah Compliant Stocks Co-Integrated? An Evidence from India

Dimpfl and Kleiman (2017), identify relationship between German stock market and sentiment of retail investors. Authors analyzed the sentiment captured by the IPIs of weekly changes in the predictive power. Study found that an increase in retail investor pessimism is accompanied by decreasing contemporaneous market returns and an increase in volatility and trading volume. Future returns tend to increase while future volatility and trading volume decrease.

Khan and Ahmad (2019), identify lead-lag relationship between returns of the market and sentiment of the investors. Data were gathered from stock market of Pakistan, from the period of 2006 to 2016. The study reveals nine indirect proxies and other direct proxy on Google search volume index. It finds sufficient evidence of irrational behavior of investors in the thin market of Pakistan.

Curme, Stanley, Moat, and Preis (2014) analyze stock market moves with search value index. Data were collected from 2004 to 2012 yearly. Research reveals that there is a relationship between stock market moves and internet search. Which is related to business and politics. It also found that stock market falls because of increase in search volume by general people.

Dimp and Jank (2011) identify stock market volatility and retail investor's attention by queries of internet search. The researcher found that Search queries are useful to predict volatility. It also improves the different forecasting horizons in-sample and out-of-sample as well. Search queries contain additional information about market volatility.

Latoeiro, Ramos, and Veiga (2013) predict stock market activity using web search queries. Researcher used the data from European stock market. Study found that an increase for web search queries for the market index leads to a decrease in the returns of the index as well as of the stock index futures and an increase in implied volatility.

Curme, Stanley, Moat, and Preis (2014) explore search terms related with finance by using Google query volumes. Result of the study found patterns that may be interpreted as "early warning signs" of stock market moves. It further explains that for better understanding of collective human behavior this behavioral set is very useful.

Bijl, et al (2016) explored the volatility of stock returns can be identified by using trends on Google. They further analyze trading strategy based on selling stocks with high Google search volumes and buying stocks with infrequent Google searches. The data were collected from the period 2008 
Irfan | Do Google Trends and Shariah Compliant Stocks Co-Integrated? An Evidence from India

to 2013. Result of the study declared that it leads negative return when there is high search on Google. Research further finds that when transaction cost is not including this strategy becomes useful.

Nasir, Huynh, Nguyen, and Duong (2019) used search values on Google trends to predict returns and volume of Bitcoin. Data were gathered from the period 2013 to 2017. The study revealed that the when there is increase in frequency of Google search tend to give positive result and it increase trading volume of Bitcoin.

Oliveira, Cortez, and Areal (2013) analyzes the six major stocks. They developed several indicators and also identify value of three markets variables. Basically, they are returns, volatility and trading volume. Data from stock twist were used in this study. Research found that there is no evidence of return predictability using sentiment indicators, and of information content of posting volume for forecasting volatility. It also suggested that posting volume can improve the forecasts of trading volume.

Huang, Rojas, and Convery (2019) investigate the different terms for S\&P 500 , researcher used the relative volume of Google searches. Kaplan- Meier test used for analyses. Study declared that there is high persistence relationship between search trend data and the stock market series.

Selene (2018) predict weekly changes in stock price using data from Google trend website and the Yahoo finance website. It used the conventional time series analysis technique. Data were collected events related to a selected stock and news. The result of the study shows the significant correlation between important news/events computed from the Google trend website and the changes in weekly stock prices.

\section{Methodology}

\subsection{Data}

Present study shows that the online search value intensity to measure the degree of investors' interest on the particular item. Data were collected from the Google Trends (https://trends.google.com/trends/) (Bank et al. 2011). Google Trends provided time series data is called GSVI (Google search value index) on the behalf of frequency of searches of a specific keywords viz., companies, Industries, indices, stock market at a time and location specified 
Irfan | Do Google Trends and Shariah Compliant Stocks Co-Integrated? An Evidence from India

by the user (Joseph et al. 2011). GSVI has given time series data in numbers, which is in the scale of 0 and 100 (Takeda \& Wakao, 2014).

Solely secondary data has been used for the study pertaining to the Shariah compliant stocks from the Shariah Indices of India respectively Nifty500 Shariah, Nifty50 Shariah and Nifty25 Shariah Index. Shariah Indices were working since 2007 in India. The aim of study is to examine the relationship between google search index value and Shariah compliant stocks movements in India. The sample of study consists of 10 Shariah compliant stocks, which are commonly available in the all the three Shariah indices in India. Because these Shariah compliant have filter criteria to select the stock on quarterly basis. These selected Shariah compliant stocks were filtered and continuously working in the Shariah indices since Sept 2014. The data is spread over the six years from Sept 2014 to Sept 2019 with 261 weekly data points of the observations.

The weekly price information on Shariah indices including Shariah compliant stocks data collected from Yahoo finance and Google search value index collected from Google trends.

\subsection{Model Development}

The data extracted of selected Shariah compliant stocks from the premier source for global media property i.e. Yahoo! network special from the Yahoo! Finance. Google trends: Analyses the popularity of top search queries (Da et al. 2011). More recent studies have used aggregate the search value frequency in Google trends. Investors search intention world wide data have been collected from google trends (Joseph et al. 2011). Table:1, shows that the search keywords on Google finance and Yahoo! Finance.

Table 1. Search Keywords on Google Finance and Yahoo! Finance

\begin{tabular}{clll}
\hline Indices & \multicolumn{1}{c}{ Shariah Compliant Stocks } & Yahoo Finance & \multicolumn{1}{c}{ Google Trends } \\
\hline & Infosys Ltd. & INFY.NS & Information Technology Consulting Co. \\
& Tata Consultancy Services Ltd. & TCS.NS & Tata Communication Services \\
Nifty & Hindustan Unilever Ltd. & HINDUNILVR.NS & Hindustan Unilever Company \\
Shariah25, & Asian Paints Ltd. & ASIANPAINT.NS & Asian Paints Company \\
Nifty50 & HCL Technologies Ltd. & HCLTECH.NS & Information Technology Company \\
Shariah, & Titan Company Ltd. & TITAN.NS & Titan Company \\
Shariah & Tech Mahindra Ltd. & TECHM.NS & Information Technology Company \\
& Oil \& Natural Gas Corporation Ltd. & ONGC.NS & Oil \& Natural Gas Corporation Co. \\
& Hero MotoCorp Ltd. & HEROMOTOCO.NS & Auto Maker Company \\
& Britannia Industries Ltd. & BRITANNIA.NS & Food Company \\
\hline
\end{tabular}


Irfan | Do Google Trends and Shariah Compliant Stocks Co-Integrated? An Evidence from India

As per the direction of objective, this study is based on time series data. There is requirement of smooth showing the data, first, researcher required to calculate the summary of statistics. The diagnostic analysis is based on three different tests i.e., the residual test, stability test and coefficient test. Residual test is demonstrated by LM Test, which shows that serial correlation. CUSUM test following the stability in the data and coefficient test depends upon the Wald test, which shows that the short run causality in the data (Gujarati, 2004).

To check the stationarity of data, then just go to used ADF test (Augmented Dickey-Fuller Test Statistic), Significance of ADF test, standardized that T-test statistic is more than the critical value and $p$ value is less than $5 \%$ (Irfan, 2017).

\subsection{Method}

As per the direction of objective, this study is based on time series data. There is requirement of smooth showing the data, first, researcher required to calculate the summary of statistics. The diagnostic analysis is based on three different tests i.e., the residual test, stability test and coefficient test. Residual test is demonstrated by LM Test, which shows that serial correlation. CUSUM test following the stability in the data and coefficient test depends upon the Wald test, which shows that the short run causality in the data (Gujarati, 2004).

To check the stationarity of data, then just go to used ADF test (Augmented Dickey-Fuller Test Statistic), Significance of ADF test, standardized that T-test statistic is more than the critical value and $p$ value is less than $5 \%$ (Irfan, 2017).

$\Delta y_{t}=\alpha+\gamma y_{t-1}+\sum_{i=1}^{P} \Delta y_{t-i}+\varepsilon_{t}$

Where $y_{-} t$ is being tested series and $\nu_{-}(t-i)$ is the 1 st difference in the series. Therefore, $\mathrm{Ho}: \mathrm{\gamma}=0$ and $\mathrm{H} 1: \mathrm{\gamma}<0$, these hypotheses are respectively used as null and alternative that the series has a unit root, meaning that it is non-stationary when the ADF test vale is less that critical value (Enders, 2014).

To measure the indication of co-integration equations between the Shariah compliant stocks and Google trends (GSVI), adopted the Johansen co-integration test. It shows that the long run relationship between the variables, where Trace statistics and Max -Eigen statistic 
Irfan | Do Google Trends and Shariah Compliant Stocks Co-Integrated? An Evidence from India

value are significant at the level of 5 percent (Medeiros, Van Doornik, \& Oliveira, 2011), (Irfan, 2016).

$$
\begin{aligned}
& \lambda_{\text {trace }}(r / k)=-T \sum_{i-r+1}^{k} \log \left(1-\lambda_{i}\right) \\
& \lambda_{\text {max }}(r / r+1)=-T \log \left(1-\lambda_{r+1}\right)
\end{aligned}
$$

Here, null hypothesis shows that the $r$ is number of the co-integrated vectors in the series, $T$ is usually shown that the number of the observation and $\lambda t$ is estimated the nth eigenvalue. Trace statistic set the where null hypothesis, identify the number of co-integrated vector in the series, which is less than, equal to $r$ and opposite the alternative hypothesis (Johansen \& Juselius, 1990).

To identify the casual relationship between selected Shariah compliance stocks (SCS) and Google trends (GSVI), researcher run the Vector Error Correction Model (VECM) to know the acceptability of model (Sims, 1980). A VECM model can be represented in the following way:

$\Delta y_{t}=\prod_{1} y_{t-k}+\Gamma_{1} \Delta y_{t-1}+\Gamma_{2} \Delta y_{t-2}+\cdots+\Gamma_{k-1} \Delta y_{t-(k-1)}+u_{t}$

Here,

$\left.\Pi=\left(\sum_{j-1}^{k} \beta i\right)-I g, \quad \Gamma i=\sum_{j-1}^{i} \beta j\right)-I g, \Delta y_{t}$ is a vector of difference with $\mathrm{n}$ variables, $\Sigma$ is the matrix of $u_{t}$ variance, $\mathrm{g}$ indicates variables of the VECM model, which is the left side variables in the equation and $k-1$ is the dependent variable lags on the right side of equation, both the side associated with a coefficient matrix Гi (Johansen \& Juselius, 1990).

Co-integration relationships in the system require that a Vector of Error Correction Model (VECM) be used instead of a VAR model. The VECM models as developed by Engle and Granger (1987) have as their aim the insertion of short-term adjustments due to the presence of cointegration (Medeiros, Van Doornik, \& Oliveira, 2011). Further explanation of VECM model according to the cluster of the Shariah compliance stocks (SCS) and Google trends (GSVI).

$$
\begin{aligned}
& \Delta S C S_{t}=\alpha S C S_{0}+\sum_{i=1}^{p-1} \alpha S C S_{i} \Delta G S V I_{t-1}+\sum_{i=1}^{p-1} \beta S C S_{i} \Delta S C S_{t-1}+ \\
& \alpha S C S Z_{t-1}+\varepsilon S C S_{t} \\
& \Delta G S V I_{t}=\alpha G S V I_{0}+\sum_{i=1}^{p-1} \alpha G S V I_{i} \Delta S C S_{t-1}+\sum_{i=1}^{p-1} \beta G S V I_{i} \Delta G S V I_{t-1}+ \\
& \alpha G S V I Z_{t-1}+\varepsilon G S V I_{t}
\end{aligned}
$$


Irfan | Do Google Trends and Shariah Compliant Stocks Co-Integrated? An Evidence from India

Where $S C S_{t}$ and $G S V I_{t}$ are Shariah compliance stocks and Google trends series respectively. $\alpha S C S_{0}$ is the intercept for Shariah Compliant Stocks series and $\alpha G S V I_{0}$ is the intercept for Google trends series. $\alpha G S V I_{i}, \alpha S C S_{i}$, $B G S V I_{i}$, and $B^{B S C S_{i}}$ are short term coefficients for Shariah compliance stocks and Google trends series. $Z_{t-1}$ is the error correction term for respective equations.

\section{Results and Analysis}

\subsection{Result}

Time series data analysis will carry the explained empirical finding, which will be follow the in the policy, implication and amendments are suggested. Which will be also unlock the new opportunities in broad area of Shariah compliance stocks and Google trends (GSVI).

Table 2. Descriptive statistics of Shariah Compliant Stocks

\begin{tabular}{|c|c|c|c|c|c|c|c|c|c|c|}
\hline Parameters & Infosys & TCS & HUL & $\begin{array}{l}\text { Asian } \\
\text { Paints }\end{array}$ & $H C L$ & Titan & $\begin{array}{c}\text { Tech } \\
\text { Mahi. }\end{array}$ & ONGC & $\begin{array}{l}\text { Hero } \\
\text { Moto }\end{array}$ & Britannia \\
\hline Mean & 575.33 & 1472.44 & 1168.33 & 1079.15 & 905.90 & 614.23 & 578.40 & 157.60 & 3070.73 & 1963.90 \\
\hline Std. Dev. & 94.50 & 353.21 & 378.39 & 238.20 & 99.58 & 289.25 & 117.73 & 23.08 & 440.00 & 737.51 \\
\hline Kurtosis & -0.37 & -0.64 & -1.28 & -0.96 & -0.77 & -0.99 & -1.10 & -0.27 & -1.11 & -1.19 \\
\hline Skewness & 0.81 & 0.99 & 0.58 & 0.13 & 0.29 & 0.68 & 0.24 & 0.25 & 0.24 & 0.26 \\
\hline Min. & 442.15 & 1050.57 & 720.35 & 628.70 & 717.50 & 303.30 & 380.00 & 110.73 & 2292.55 & 665.90 \\
\hline Max. & 840.15 & 2259.60 & 1881.90 & 1615.20 & 1143.05 & 1334.70 & 831.80 & 219.66 & 4047.30 & 3386.73 \\
\hline Parameters & $\begin{array}{l}\text { Log- } \\
\text { Infosys }\end{array}$ & log-TCS & $\log -\mathrm{HUL}$ & $\begin{array}{l}\text { log- } \\
\text { Asian } \\
\text { Paints }\end{array}$ & $\log -\mathrm{HCL}$ & $\begin{array}{l}\text { log- } \\
\text { Titan }\end{array}$ & $\begin{array}{l}\text { log- } \\
\text { Tech } \\
\text { Mahi. }\end{array}$ & $\begin{array}{c}\text { log- } \\
\text { ONGC }\end{array}$ & $\begin{array}{c}\text { log-Herc } \\
\text { Motor }\end{array}$ & $\begin{array}{c}\log - \\
\text { Britannia }\end{array}$ \\
\hline Mear & 27 & 0.23 & 0.39 & 0.37 & 0.1 & 0.46 & 0.12 & -0.14 & 0.03 & 0.5 \\
\hline Std. Dev. & .05 & 3.20 & 2.89 & 3.04 & 3.3 & 3.72 & 3.67 & 3.75 & 3.54 & 3.47 \\
\hline Kurtosis & 0.36 & 0.44 & 1.63 & 0.55 & 2.02 & 3.72 & 1.78 & 1.82 & 0.41 & 1.20 \\
\hline Skewness & -0.17 & -0.13 & 0.43 & -0.08 & -0.54 & 0.67 & -0.15 & -0.16 & 0.36 & 0.02 \\
\hline Min. & -8.48 & -9.84 & -7.94 & -8.07 & -13.35 & -13.84 & -16.89 & -17.01 & -9.17 & -10.42 \\
\hline Max. & 8.56 & 8.59 & 14.37 & 11.45 & 9.14 & 18.54 & 12.62 & 13.47 & 10.90 & 13.88 \\
\hline
\end{tabular}

Table 2, in the outcomes of Shariah compliant stocks std. dev. are more than 3 in the all selected stocks meaning that all are highly risky stocks. In the case of skewness all are positive means all the stocks have high value more in comparison to the low values in time series. Summarizes the data in significant ways of the Shariah compliant stocks log. The standard deviation shows the volatility, which is more than 3 percent, meaning that 9 selected Shariah stocks are high volatile, but only HUL has $2.89 \mathrm{Std}$. Dev. which is less volatile. Skewness of the distribution of Infosys, TCS, Asian Paints, $\mathrm{HCl}$, Tech Mahi, ONGC data are negative left skewed that means no. of low values are more in comparison high values in the data. 
Irfan | Do Google Trends and Shariah Compliant Stocks Co-Integrated? An Evidence from India

Table 3. Descriptive statistics of Google Search Value Index (GSVI)

\begin{tabular}{lcccccccccc}
\hline Parameters & Infosys & \multirow{2}{*}{ TCS } & HUL & $\begin{array}{c}\text { Asian } \\
\text { Paints }\end{array}$ & HCL & Titan & $\begin{array}{c}\text { Tech } \\
\text { Mahi. }\end{array}$ & ONGC & $\begin{array}{c}\text { Hero } \\
\text { Moto }\end{array}$ & Britannia \\
\hline Mean & 25.12 & 52.71 & 50.95 & 48.75 & 65.62 & 62.20 & 58.01 & 33.14 & 38.38 & 37.56 \\
Std. Dev. & 8.25 & 11.39 & 11.39 & 10.87 & 11.70 & 13.22 & 10.63 & 10.98 & 9.47 & 16.73 \\
Kurtosis & 28.00 & 1.55 & 2.25 & 2.04 & 0.30 & -0.32 & 0.30 & 7.07 & 7.38 & 1.06 \\
Skewness & 3.90 & 1.15 & 1.36 & 1.01 & 0.82 & 0.77 & 0.58 & 2.19 & 1.93 & 1.34 \\
Min. & 14.00 & 33.00 & 33.00 & 31.00 & 39.00 & 41.00 & 34.00 & 18.00 & 26.00 & 17.00 \\
Max. & 100 & 100 & 100 & 100 & 100 & 100 & 100 & 100 & 100 & 100 \\
\hline \multirow{4}{*}{ Parameters } & Log- & log- & log- & log- & \multirow{2}{*}{ log- } & log- & log- & log- & log- & log- \\
& Infosys & TCS & HUL & Asian & HCL & Titan & Tech & ONGC & Hero & Britannia \\
\hline Mean & 2.41 & 1.04 & 0.94 & 0.56 & 0.34 & 0.56 & 1.27 & 1.44 & 0.87 & 1.68 \\
Std. Dev. & 26.38 & 15.50 & 13.70 & 9.87 & 10.44 & 8.41 & 17.08 & 19.42 & 13.98 & 16.51 \\
Kurtosis & 27.94 & 2.46 & 1.37 & 3.47 & 2.24 & 0.91 & 4.47 & 1.81 & 100.79 & 1.15 \\
Skewness & 4.05 & 0.42 & 0.65 & -0.69 & 0.83 & 0.60 & 1.18 & 0.75 & 7.48 & 0.68 \\
Min. & -47.06 & -37.93 & -31.91 & -41.51 & -28.33 & -20.90 & -40.35 & -48.65 & -63.00 & -38.36 \\
Max. & 226.32 & 75.44 & 53.19 & 29.87 & 49.09 & 34.72 & 100.00 & 93.10 & 177.78 & 61.40 \\
\hline
\end{tabular}

Table 3 summarizes the data in significant ways of the selected Shariah compliant of GSIV. Skewness of the distribution of GSIV and GSVIlog is positive right skewed that means no. of high values are more in comparison low values in the time series data. The standard deviation shows the volatility of GSVI selected Shariah stocks, which is more than 3 percent, meaning that all selected Shariah stocks are highly volatile. In log series of GSVI summary reflection of row data.

Table 4. Unit Root Test on Shariah Compliant Stocks and GSVI

\begin{tabular}{lccccc}
\hline $\begin{array}{l}\text { Augmented Dickey-Fuller test statistic Null } \\
\text { Hypothesis: }\end{array}$ & 1\% level & 5\% level & 10\% level & t-Statistic & Prob.* \\
\hline Shariah compliant stocks has a unit root & -3.455 & -2.872 & -2.573 & -0.643 & 0.857 \\
ASIAN_PAINTSG has a unit root & -3.457 & -2.873 & -2.573 & -9.592 & 0.115 \\
BRITANNIAG has a unit root & -3.455 & -2.872 & -2.573 & -2.433 & 0.134 \\
HCLG has a unit root & -3.456 & -2.873 & -2.573 & -2.728 & 0.171 \\
HERO_MOTOG has a unit root & -3.456 & -2.873 & -2.573 & -3.426 & 0.111 \\
HULG has a unit root & -3.456 & -2.873 & -2.573 & -1.467 & 0.549 \\
INFOSYSG has a unit root & -3.455 & -2.872 & -2.573 & -7.643 & 0.146 \\
ONGCG has a unit root & -3.456 & -2.873 & -2.573 & -8.600 & 0.113 \\
TCSG has a unit root & -3.456 & -2.873 & -2.573 & -7.335 & 0.254 \\
TECH_MAHINDRAG has a unit root & -3.456 & -2.873 & -2.573 & -3.912 & 0.233 \\
TITANG has a unit root & -3.456 & -2.873 & -2.573 & -1.003 & 0.753 \\
\hline
\end{tabular}

Table 4 the results of Augmented Dickey-Fuller (ADF) test for selected Shariah compliant stock benchmark. As shown, the null hypothesis of nonstationarity for the ADF tests is accept, indicating that Shariah compliant stocks data are non-stationary in level. P-value is more than $5 \%$. Meaning that all-time series data become non stationary after applying the coefficient should be negative and $p$-value should be less than $5 \%$. Although researcher can run the further test of co-integration. 
Irfan | Do Google Trends and Shariah Compliant Stocks Co-Integrated? An Evidence from India

\section{Robustness test of Shariah Compliant stocks and GSVI}

Table 5. Breusch-Godfrey Serial Correlation LM Test

\begin{tabular}{|c|c|c|c|c|}
\hline \multirow{2}{*}{ ASIAN PAINTS } & F-statistic & 8.857 & Prob. $F(2,256)$ & 0.200 \\
\hline & Obs*R-squared & 16.827 & Prob. Chi-Square(2) & 0.300 \\
\hline \multirow{2}{*}{ BRITANNIA } & F-statistic & 0.190 & Prob. F(2,256) & 0.828 \\
\hline & Obs*R-squared & 0.384 & Prob. Chi-Square(2) & 0.825 \\
\hline \multirow{2}{*}{$\mathrm{HCL}$} & F-statistic & 0.749 & Prob. $F(2,256)$ & 0.474 \\
\hline & Obs*R-squared & 1.512 & Prob. Chi-Square(2) & 0.470 \\
\hline \multirow{2}{*}{ HERO MOTOR } & F-statistic & 1.308 & Prob. F(2,256) & 0.272 \\
\hline & Obs*R-squared & 2.629 & Prob. Chi-Square(2) & 0.269 \\
\hline \multirow{2}{*}{ HUL } & F-statistic & 0.719 & Prob. F(2,256) & 0.488 \\
\hline & Obs*R-squared & 1.452 & Prob. Chi-Square(2) & 0.484 \\
\hline \multirow{2}{*}{ INFOSYS } & F-statistic & 0.984 & Prob. $F(2,256)$ & 0.375 \\
\hline & Obs*R-squared & 1.984 & Prob. Chi-Square(2) & 0.371 \\
\hline \multirow{2}{*}{ ONGC } & F-statistic & 2.659 & Prob. $F(2,256)$ & 0.072 \\
\hline & Obs*R-squared & 5.291 & Prob. Chi-Square(2) & 0.071 \\
\hline \multirow{2}{*}{ TCS } & F-statistic & 0.667 & Prob. F(2,256) & 0.514 \\
\hline & Obs*R-squared & 1.348 & Prob. Chi-Square(2) & 0.510 \\
\hline \multirow{2}{*}{ TECH MAHINDRA } & F-statistic & 1.853 & Prob. F(2,256) & 0.159 \\
\hline & Obs*R-squared & 3.710 & Prob. Chi-Square(2) & 0.156 \\
\hline \multirow[t]{2}{*}{ TITAN } & F-statistic & 0.540 & Prob. F(2,256) & 0.583 \\
\hline & Obs*R-squared & 1.093 & Prob. Chi-Square(2) & 0.579 \\
\hline
\end{tabular}

Table 5, shown that the residual diagnostic, first check the serial correlation in the data. Here, Observed R-squared and p-value is more than $5 \%$ in selected Shariah compliant stocks and GSVI, researcher cannot reject the null hypothesis rather accept the null hypothesis meaning that there is no serial correlation exist between the GSVI and Shariah compliant stocks.

\section{Stability Diagnostic Pattern Chart}

Represent the stability diagnostic analysis by recursive estimation of CUSUM test and CUSUM of squares test, we can see the middle line of individual Shariah stocks in between the resistance and support line, meaning that there is stability in selected Shariah compliant stocks in with benchmark and GSVI. Brittannia, HCL, HUL and Titan data have stable in CUSUM test, in the other side Asian Paints, Hero Motors, ONGC, Infosys, TCS and Tech Mahindra have also shown stable in nature when we run the CUSUM of squares test. 
Irfan | Do Google Trends and Shariah Compliant Stocks Co-Integrated? An Evidence from India

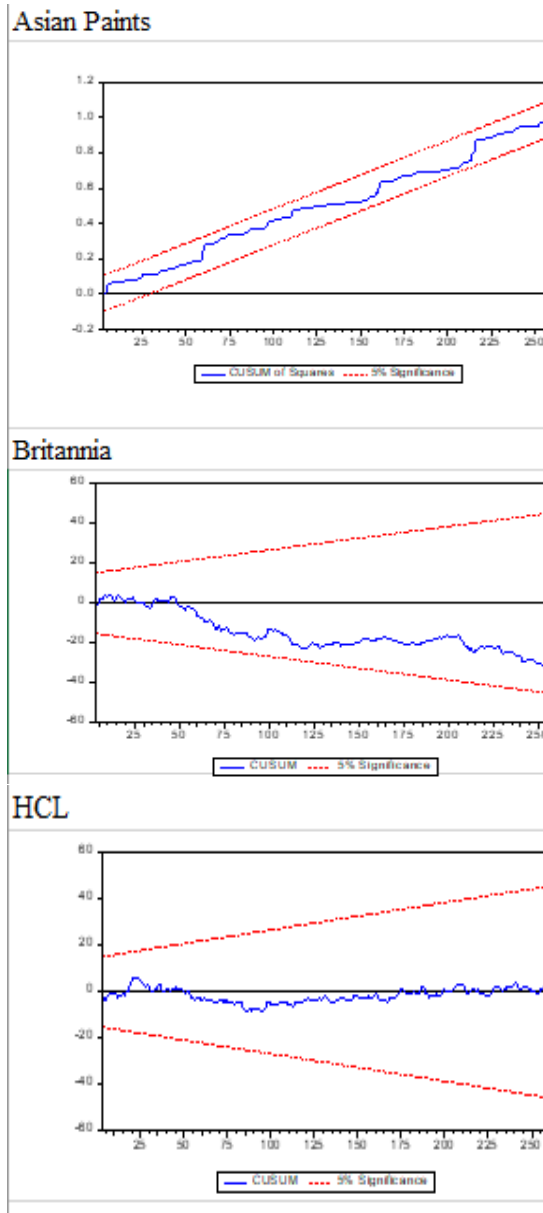

Infosys

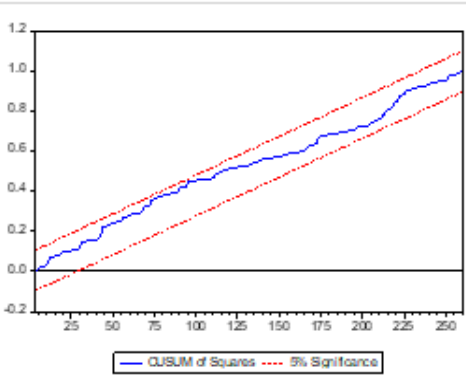

ONGC

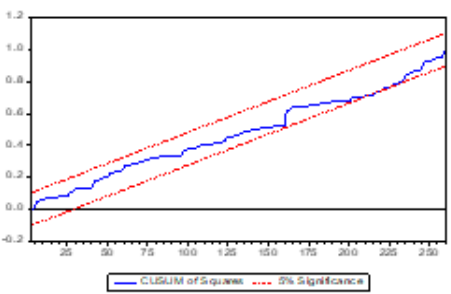

TCS

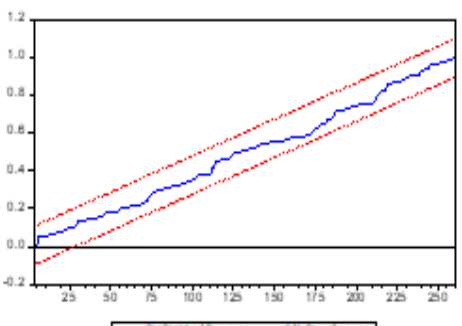

Hero Motors

Tech Mahindra

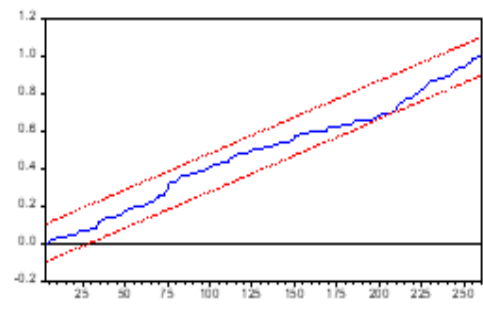

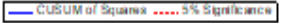

HUL
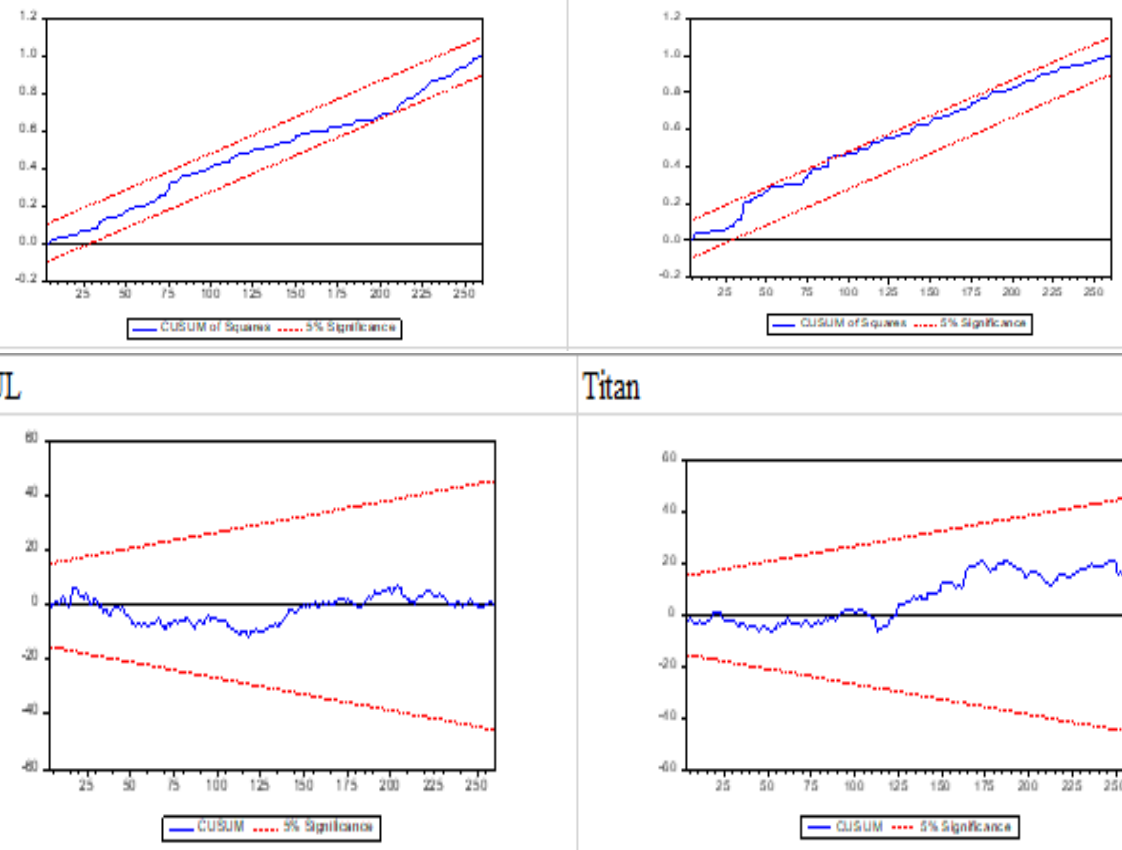

itan

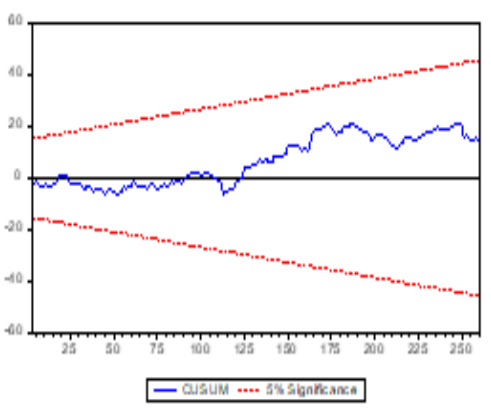

Figures 1. Recursive Estimation of CUSUM and CUSUM of squares test. 
Irfan | Do Google Trends and Shariah Compliant Stocks Co-Integrated? An Evidence from India

Table 6. Wald Test Coefficient Diagnostic

\begin{tabular}{clccc}
\hline Shariah Compliant Stocks & Test Statistic & Value & Df & Probability \\
\hline \multirow{2}{*}{ ASIAN PAINTS } & F-statistic & 1.048 & $(2,258)$ & 0.352 \\
& Chi-square & 2.097 & 2 & 0.351 \\
\multirow{2}{*}{ BRITANNIA } & F-statistic & 5.725 & $(2,258)$ & 0.004 \\
& Chi-square & 11.449 & 2 & 0.003 \\
HCL & F-statistic & 0.513 & $(2,258)$ & 0.599 \\
& Chi-square & 1.026 & 2 & 0.599 \\
HERO MOTOR & F-statistic & 0.243 & $(2,258)$ & 0.784 \\
& Chi-square & 0.486 & 2 & 0.784 \\
\multirow{3}{*}{ HUL } & F-statistic & 3.280 & $(2,258)$ & 0.039 \\
& Chi-square & 6.561 & 2 & 0.038 \\
\multirow{2}{*}{ INFOSYS } & F-statistic & 1.732 & $(2,258)$ & 0.179 \\
& Chi-square & 3.464 & 2 & 0.177 \\
\multirow{2}{*}{ ONGC } & F-statistic & 1.644 & $(2,258)$ & 0.195 \\
& Chi-square & 3.288 & 2 & 0.193 \\
\multirow{2}{*}{ TCS } & F-statistic & 0.769 & $(2,258)$ & 0.465 \\
& Chi-square & 1.538 & 2 & 0.463 \\
& F-statistic & 0.233 & $(2,258)$ & 0.792 \\
TECH MAHINDRA & Chi-square & 0.467 & 2 & 0.792 \\
& F-statistic & 6.093 & $(2,258)$ & 0.003 \\
\multirow{2}{*}{ TITAN } & Chi-square & 12.185 & 2 & 0.002 \\
\hline
\end{tabular}

Table 6, Coefficient diagnostic i.e., Wald test: Coefficient restrictions, here null hypothesis is $C(1)=C(2)=0$ jointly. Results are shown that accept the null hypothesis, there is no short run causality running between selected Shariah compliant stocks and GSVI.

Table 7. Lag Selection of Optimal Order

\begin{tabular}{ccclcrc}
\hline Lag & LogL & LR & \multicolumn{1}{c}{ FPE } & AIC & SC & HQ \\
\hline 0 & -10118.24 & 0.000 & $3.9 \mathrm{E}+22$ & 80.383 & 80.53 & 80.44 \\
1 & -9971.48 & 280.699 & $2.7 \mathrm{E}+22$ & 80.012 & 81.552 & 80.632 \\
2 & -9851.461 & 220.036 & $2.7 \mathrm{e}+22^{*}$ & $79.86^{*}$ & $82.794^{*}$ & $81.036^{*}$ \\
3 & -9766.775 & 148.536 & $2.6 \mathrm{E}+22$ & 79.974 & 84.316 & 81.721 \\
4 & -9687.641 & 132.519 & $3.1 \mathrm{E}+22$ & 80.140 & 85.882 & 82.451 \\
5 & -9614.957 & 115.948 & $4.0 \mathrm{E}+22$ & 80.357 & 87.500 & 83.231 \\
6 & -9543.033 & 109.027 & $5.2 \mathrm{E}+22$ & 80.580 & 89.123 & 84.017 \\
7 & -9462.665 & 115.450 & $6.4 \mathrm{E}+22$ & 80.735 & 90.679 & 84.737 \\
8 & -9368.131 & $128.2963^{*}$ & $7.2 \mathrm{E}+22$ & 80.779 & 92.123 & 85.344 \\
\hline
\end{tabular}

Table 7, Here * indicate lag order selected by criteria. In the first case of LR * indicate on the $8 \mathrm{lag}$, meaning that $8 \mathrm{lag}$ should be chosen. Second criteria is $\mathrm{FPE} *$ indicate on the $2 \mathrm{lag}$, in the case of AIC, selection criteria is lower the value better the model meaning that lag 2 is chosen. Same criteria followed $\mathrm{SC}$ and $\mathrm{HQ}$, lower the values better the model. According to the $\mathrm{SC}$ and $\mathrm{HQ}$ lag 2 should be selected. Now actually all criteria are good, but here majority of criteria recommended that 2 . The optimum lag would be 2 , researchers shall be using the 2 lag for the Johnson test and vector auto regression. 
Irfan | Do Google Trends and Shariah Compliant Stocks Co-Integrated? An Evidence from India

Table 8. Johansen Test of Co-integration of Shariah Compliant Stocks and GSVI

\begin{tabular}{|c|c|c|c|c|}
\hline $\begin{array}{l}\text { Hypothesized } \\
\text { No. of CE(s) }\end{array}$ & Eigenvalue & Trace Statistic & $\begin{array}{c}\text { Critical Value } \\
0.05\end{array}$ & Prob.** \\
\hline None ${ }^{*}$ & 0.274 & 371.705 & 285.143 & 0.000 \\
\hline At most $1 *$ & 0.215 & 289.749 & 239.235 & 0.000 \\
\hline At most $2 *$ & 0.203 & 227.845 & 197.371 & 0.001 \\
\hline At most $3^{*}$ & 0.155 & 169.856 & 159.530 & 0.012 \\
\hline At most $4^{*}$ & 0.123 & 126.783 & 125.615 & 0.042 \\
\hline At most 5 & 0.098 & 93.152 & 95.754 & 0.075 \\
\hline At most 6 & 0.090 & 66.885 & 69.819 & 0.084 \\
\hline At most 7 & 0.070 & 42.637 & 47.856 & 0.142 \\
\hline At most 8 & 0.047 & 24.184 & 29.797 & 0.193 \\
\hline At most 9 & 0.043 & 11.787 & 15.495 & 0.167 \\
\hline At most 10 & 0.002 & 0.428 & 3.841 & 0.513 \\
\hline
\end{tabular}

Trace test is indicates 5 co-integrating equation(s) at the 0.05 level, * denotes rejection of the hypothesis at the 0.05 level, **MacKinnon-HaugMichelis (1999) p-values. The outcomes of table 8 shown that there are 5 cointegration equation exist between Shariah compliant stocks GSVI. Meaning that there is long run relationship with in two cluster.

Table 9. Johansen Test, of Co-integration of Shariah Compliant Stocks and GSVI

\begin{tabular}{lcccc}
\hline $\begin{array}{l}\text { Hypothesized } \\
\text { No. of CE(s) }\end{array}$ & Eigenvalue & Max Eigenvalue & $\begin{array}{c}\text { Critical Value } \\
0.05\end{array}$ & Prob.** $^{* *}$ \\
\hline None & 0.274 & 81.955 & 70.535 & 0.003 \\
At most 1 & 0.215 & 61.904 & 64.505 & 0.087 \\
At most 2 & 0.203 & 57.990 & 58.434 & 0.055 \\
At most 3 & 0.155 & 43.073 & 52.363 & 0.321 \\
At most 4 & 0.123 & 33.631 & 46.231 & 0.549 \\
At most 5 & 0.098 & 26.267 & 40.078 & 0.684 \\
At most 6 & 0.090 & 24.248 & 33.877 & 0.438 \\
At most 7 & 0.070 & 18.453 & 27.584 & 0.458 \\
At most 8 & 0.047 & 12.397 & 21.132 & 0.509 \\
At most 9 & 0.043 & 11.359 & 14.265 & 0.137 \\
At most 10 & 0.002 & 0.428 & 3.841 & 0.513 \\
\hline
\end{tabular}

Max Eigen value test Statistics is indicates 1 co-integrating equation(s) at the 0.05 level, * denotes rejection of the hypothesis at the 0.05 level, **MacKinnon-Haug-Michelis (1999) p-values. The outcomes of the Johansen's Max Eigen-value tests are shown in Table 9 where it is found that there is 1 co-integration equation among Shariah compliant stocks and GSVI. Therefore, it can be concluded that there is long-run or equilibrium relationship between selected Shariah compliant stocks and GSVI. 
Irfan | Do Google Trends and Shariah Compliant Stocks Co-Integrated? An Evidence from India

Table 10. Vector Error Correction Model (VECM) of Shariah Compliant stocks and GSVI

\begin{tabular}{|c|c|c|c|c|}
\hline Parameters & Coefficient & Std. Error & t-Statistic & Prob. \\
\hline$C(1)$ & -0.004 & 0.004 & -0.925 & 0.026 \\
\hline$C(2)$ & -0.031 & 0.067 & -0.470 & 0.064 \\
\hline$C(3)$ & -0.002 & 0.067 & -0.031 & 0.075 \\
\hline$C(4)$ & -0.335 & 0.358 & -0.936 & 0.035 \\
\hline$C(5)$ & -0.165 & 0.335 & -0.492 & 0.052 \\
\hline$C(6)$ & -0.238 & 0.245 & -0.969 & 0.033 \\
\hline$C(7)$ & -0.126 & 0.250 & -0.502 & 0.062 \\
\hline$C(8)$ & -0.428 & 0.281 & -1.527 & 0.013 \\
\hline$C(9)$ & -0.363 & 0.281 & -1.290 & 0.020 \\
\hline$C(10)$ & -0.180 & 0.284 & -0.634 & 0.053 \\
\hline$C(11)$ & -0.198 & 0.243 & -0.814 & 0.042 \\
\hline$C(12)$ & -0.375 & 0.274 & -1.366 & 0.017 \\
\hline$C(13)$ & -0.096 & 0.239 & -0.401 & 0.069 \\
\hline$C(14)$ & -0.100 & 0.218 & -0.457 & 0.065 \\
\hline$C(15)$ & -0.035 & 0.216 & -0.163 & 0.071 \\
\hline$C(16)$ & 0.178 & 0.203 & 0.874 & 0.138 \\
\hline$C(17)$ & -0.159 & 0.200 & -0.794 & 0.043 \\
\hline$C(18)$ & 0.176 & 0.176 & 1.002 & 0.172 \\
\hline$C(19)$ & -0.014 & 0.175 & -0.081 & 0.036 \\
\hline$C(20)$ & -0.322 & 0.198 & -1.626 & 0.011 \\
\hline$C(21)$ & 0.006 & 0.194 & 0.033 & 0.073 \\
\hline$C(22)$ & -0.060 & 0.275 & -0.217 & 0.053 \\
\hline$C(23)$ & -0.172 & 0.286 & -0.601 & 0.055 \\
\hline$C(24)$ & 2.320 & 1.417 & 1.637 & 0.100 \\
\hline R-squared & 0.582 & \multicolumn{2}{|c|}{ Mean dependent var } & 2.227542 \\
\hline Adjt R-squared & 0.571 & \multicolumn{2}{|c|}{ S.D. dependent var } & 22.12054 \\
\hline S.E. of regression & 22.378 & \multicolumn{2}{|c|}{ Akaike info criterion } & 9.142467 \\
\hline Sum squared resid & 117184 & \multicolumn{2}{|c|}{ Schwarz criterion } & 9.472975 \\
\hline Log likelihood & -1358.2 & \multicolumn{2}{|c|}{ Hannan-Quinn criter. } & 9.275366 \\
\hline F-statistic & 0.744 & \multicolumn{2}{|c|}{ Durbin-Watson stat } & 2.004435 \\
\hline Prob(F-statistic) & 0.045 & & & \\
\hline
\end{tabular}

Table 10, after the analyzing the results co-integration, Researcher found that there is co-integration equations in between Shariah compliant stocks and GSVI. Now researcher identify the error correction term i.e., VECM model. The outcome of error correction term found that $C(1)$ to $C(24)$ coefficient are negative in sign and significant. Meaning that there is long run causality running in between Shariah compliant stocks and GSVI. In this model value of $R$ square is 58 percent which near to 60 percent so Model is fit. F-statistic of $p$-value it is significant 0.045 which is less 5 than percent so accept the model.

\subsection{Analysis}

The objective of this paper is to examine the relationship among selected Shariah compliant stocks and GSVI. Diagnostic analysis using by the coefficient, residual and stability for judge the short run causality in the data. This paper found that there is no serial correlation, no short run causality, data are stable in the nature. ADF test shown that there is non-stationarity in two set of data i.e., selected Shariah compliant stocks and GSVI. There is cointegration relationship (long term equilibrium) within Shariah compliant 
stocks and GSVI, and also have 5 co-integration equation between the cluster of Shariah compliant stocks and cluster of GSVI. There is no short run relationship exist between the Shariah complaint stocks and GSVI, but have long run relationship between the clusters. (Takeda \& Wakao, 2014) study focused on the Japanese stocks and search intensity have positive relationship, even though somewhat weak relationship between Japanese stocks and trading volume. (Khan \& Ahmad, 2019) Stated that google search index value has uni-directional relationship with the sentiments of Pakistani people. It also shows the positive relationship. It have the bi-directional relationship between the market returns and investors sentiments. This study creates scope for both local and international investors to diversify their Islamic Investment portfolios, which will put Shariah compliant stocks in India as one of their investment destinations. VECM shows that model is fit.

\section{Conclusions and Recommendations}

\subsection{Conclusions}

The results of the study, leads to the conclusion that the returns of Shariah compliant stocks are more volatile in comparison of GSVI. Skewness measure the distribution of Infosys, TCS, Asian Paints, $\mathrm{HCl}$, Tech Mahi, ONGC data are negative left skewed that means no. of low values are more in comparison high values in Shariah compliant stocks. Skewness of GSIV and GSVI-log is positive right skewed that means no. of high values are more in comparison low values in the time series data. Robustness test shows that there is no serial correlation between Shariah compliant stocks and GSVI. Shariah compliant stocks and GSVI have stability in the time series data. There is no short run relationship, but it influenced the long run relationship. Vector error correction model shows that the model is fit.

To conclude, there are many potential investment opportunities in Islamic stock markets for the investors. Small investors can invest separately in different Shariah compliant stocks, because policy and implications do not have an impact on it. The motive of Shariah is to provide an avenue for ethical and viable investment to the investors. As it is found that Shariah stocks are homogeneous in nature, in the sense of selection criteria only otherwise individual Shariah stock has its own justification of returns and sustainable growth. 


\subsection{Recommendations}

Future Direction for Research: The present research work has been undertaken by considering the selected Shariah compliant stocks of and GSVI. The data extracted from the yahoo finance database on a weekly basis. The researchers in the future can take data for the different time period of the Shariah stocks can study the relation. Additionally, they chosen Sariah indices of the different countries like Malaysia, Indonesia, and analyze the volatility, VAR (Vector autoregressive model), Granger causality test.

Social implications: The motive of Shariah compliant stock is to provide an avenue for ethical and viable investment to the investors. The perception of the investors about the Google trends (GSVI) analyses the popularity of top searching queries in the google over a time. Basically, google trends have high more values in comparison to the lower value, meaning that people are given importance to google search queries. The investors are suggested to make the investment decision in any of the three (Nifty500 Shariah, Nifty50 Shariah, Nifty25 Shariah) Shariah indices by studying them individually. This important information enables the investors to adjust their financial portfolio and also helps the respective market regulator. Google trends is a new platform for the seek the intention of the investor perception.

India is socio-economic country where individual investors are believed invest in the small rather than the large group of complaints. This study helps to those investors who wants in individual stock. But google search index value does not reflect the individual investors is relatively small in India, where google search index value most popular search engine to know about the investor sentiments. "Price pressure hypothesis" may applies to predict the shocks will have the temporary effect on the prices, which will be need to identify by the circumstance and conditions. Practitioner would also invest in this portfolio as well as individual stock because of these stocks have financially sound with receivable account. This study will not only be advantageous for the Muslim investors, but also the other investors, Shariah practitioners, advisor, legal-regulatory firm and industrialist as well. 
Irfan $\mid$ Do Google Trends and Shariah Compliant Stocks Co-Integrated? An Evidence from India

\section{References}

Aouadi, A., Arouri, M., \& Teulon, F. (2013). Investor attention and stock market activity: Evidence from France. Economic Modelling, 8.

Bank, M., Larch, M., \& Peter, G. (2011). Google search volume and its influence on liquidity and returns of German stocks. Financial Markets and Portfolio Management, 253, 239-264.

Bijl, L., Kringhaug, G., Molnár, P., \& Sandvik, E. (2016). Google searches and stock returns. International Review of Financial Analysis, 7.

Curme, C., Stanley, H.E., Moat, H.S., \& Preis, T. (2014, 08 12). Quantifying the semantics of search behavior before stock market moves. PNAS, 111 (32), 6 .

Da, Z., Engelberg, J., \& Gao, P. (2011). In search of attention. J. of Finance, 665,1461-1499.

Dimp, T., \& Jank, S. (2011). Can internet search queries help to predict stock market volatility? 42.

Dimpfl, T., \& Kleiman, V. (2017). Investor pessimism and the german stock market: Exploring google search queries. German Economic Review, 28.

Enders, W. (2014). Applied econometric time series (4th ed.). New York: John Wiley \& Sons, Inc.

Engle, R.F., \& Granger, C.W.J. (1987). Cointegration and error-correction: representation, estimation and testing. Econometrica, 55(2), 251276.

Fama, E.F. (1976). Foundations of finance: Portfolio decisions and securities Prices. Blackwell.

Gujarati, D. (2004). Basic of Econometrics (4th ed.). NewYork: McGraw-hill.

Huang, M.Y., Rojas, R.R., \& Convery, P.D. (2019). Forecasting stock market movements using google trend searches. Empirical Economic , 1-19.

Irfan, M. (2016). A study of islamic stock indices and macroeconomic variables. International Journal of Social, Behavioral, Educational, Economic, Business and Industrial Engineering, 10(7), 2557-2565.

Irfan, M. (2017). An empirical study of price discovery in commodities future market. Indian Journal of Finance, 11(3).

Johansen, S., \& Juselius, K. (1990). Maximum likelihood estimation and inference on cointegration with application to the demand for money. Oxford Bulletin of Economics and Statistics, 52(2), 169-209. 
Irfan | Do Google Trends and Shariah Compliant Stocks Co-Integrated? An Evidence from India

Joseph, K.,Wintoki, M.B., Zhang, Z. (2011). Forecasting abnormal stock returns and trading volume using investor sentiment: Evidence from online search. International J. of Forecasting, 27, 1116 - 1127.

Kahnemanm, D. (1973). Attention and effort. Prentice-Hall: Englewood Cliffs, NJ

Khan, M. A., \& Ahmad, E. (2019). Measurement of Investor sentiment and its bi-directional contemporaneous and lead-lag relationship with returns: Evidence from Pakistan. Sustainability, 20.

Krishnan, H., V, G., \& Sureshkumar, V. (2018). Google trends and stock returns: a sstudy of investor sntirevised ments using big data. International Journal of Pure and Applied Mathematics, 6.

Latoeiro, P., B, S. R., \& Veiga, H. (2013). Predictability of stock market activity using Google search queries. Statistics and Econometrics Series 05, 52.

Laurens, R.B., Glenn, K., \& Eirik, S. (2015). Predictive power of google search volume on stock returns. 55 .

Medeiros, O.R., Van Doornik, B.F., \& Oliveira, G.R. (2011). Modeling and forecasting a firm's financial statements with a VAR-VECM Model. Brazilian Business Review, 8(3), 20-39.

Merton, R. (1987). A simple model of capital market equilibrium with incomplete information. Journal of Finance, 423, 483-510.

Narita, F., \& Yin, R. (2018). In search of information:use of google trends' data to narrow information gaps for low-income developing countries. IMF Working Papers, 51.

Nasir, M.A., Huynh, T.L., Nguyen, S.P., \& Duong, D. (2019). Forecasting cryptocurrency returns and volume using search engines. Financial Innovation, 13.

NIFTY Shariah 25. (2019, September 19). The NIFTY Shariah 25 index represents 25 Shariah compliant stocks selected based on higher free-float market capitalization and aggregate traded turnover. Retrieved from Nifty indices: https://www.niftyindices.com/indices/equity/thematic-indices/niftyshariah-25.

NIFTY50 Shariah index. (2019, September 19. The NIFTY Shariah Indices are designed to offer investors Shariah-compliant investment solutions. Retrieved from Nifty indices: https://www.niftyindices.com/indices/equity/thematic-indices/nifty50-shariah

NIFTY500 Shariah index. (2019, September 24). The NIFTY Shariah Indices are designed to offer investors Shariah-compliant investment solutions. Retrieved from Nifty indices. 
Irfan | Do Google Trends and Shariah Compliant Stocks Co-Integrated? An Evidence from India

https://www.niftyindices.com/indices/equity/thematic-indices/nifty500-shariah

NSE India. (2019). Methodology of Nifty Shariah Indices. Mumbai: NSE India.

NSE Indices. (2018, August). Methodology Document of Shariah Index. Retrieved from NSE Indices: https://www.nseindia.com/content/indices/Method_Nifty_Shariah_I ndices.pdf

Oliveira, N., Cortez, P., \& Areal, N. (2013). On the predictability of stock market behavior using stocktwits sentiment and posting volume. Progress in Artificial Intelligence , 355-365.

Preis, T., Moat, H.S., \& Stanley, H.E. (2013). Quantifying trading behavior in financial markets using google trends. Scientific Reports, 6.

Seeking Alpha. (2018, July 28). Portfolio strategy :Using google trends to predict stocks. Retrieved from Seekingalpha: https://seekingalpha.com/article/4191521-using-google-trendspredict-stocks

Selene, Y.X. (2018). Stock price forecasting using information from yahoo finance and google trend. Caliphonia: UC, Berkeley.

Sims, C.A. (1980). Macroeconomics and reality. The Econometric Society, 48(1), 1-48.

Smet, S.D. (2015-16). Predictive power of google trends analysis on Euronext Brussels stock performance. ACADEMIEJAAR, 94.

Stromberg, J. (2013, April 25). Google search terms can predict the stock market. Retrieved from www.smithsonianmag.com: https://www.smithsonianmag.com/science-nature/google-searchterms-can-predict-the-stock-market-41584532/

Takeda, F., \& Wakao, T. (2014, April). Google search intensity and its relationship with returns and trading volume of Japanese stocks. Pacific Basin Flnance Journal, 27, 1-18.

The Invest. (28, Feb 2019). Tips for using google trends data to predict market movement. Retrieved from The Invest: http://www.theinvestblog.com/tips-for-using-google-trends-data-topredict-market-movement/

Tower, P.E. (2015). Google search volume index:predicting returns, volatility and trading volumeof tech stocks. Economics Honors Thesis, 32. 
Irfan | Do Google Trends and Shariah Compliant Stocks Co-Integrated? An Evidence from India

This page is intentionally left blank

International Journal of Islamic Economics and Finance (IJIEF), 3(2), 227-250| 250 